\title{
CONCEPTUALISING ISLAMIC CREDIT CARDS BASED ON MUSHĀRAKA MUTANĀQISA
}

\author{
Ahmed M. Alkhan ${ }^{1}$, M. Kabir Hassan ${ }^{2}$ and Rashedul Hasan ${ }^{3}$ \\ ${ }^{1}$ University of Bahrain, Bahrain, ahmed.alkhan@hotmail.com \\ ${ }^{2}$ University of New Orleans, United States, kabirhassan63@gmail.com \\ ${ }^{3}$ INTI International University, Malaysia, hasanaiub05@gmail.com
}

\begin{abstract}
The purpose of this paper is to conceptualise an Islamic credit card (or mushāraka card) based on the Islamic principles of mushāraka mutanāqisa. A qualitative methodology was employed, with qualitative content analysis used on AAOIFI Shari'a Standard (SS) No. 12 "Sharikah (Musharaka) and Modern Corporations" to derive key rulings and controls for mushāraka mutanāqisa, which were then used to conceptualise an Islamic credit card based on mushāraka mutanāqisa. Theoretically, it should be possible to develop an Islamic credit card based on the Islamic rulings of mushāraka mutanāqisa. The concept provided in this paper could be adopted as a pilot project by Islamic retail banks. Evidence suggests that a new revised standard for credit cards (included within AAOIFI Shari'a Standard (SS) No. 2) was under construction while this research was being undertaken. Therefore, it was not possible to review what perhaps may be relevant information for conceptualising a new Islamic credit card. The research intends to fill the gap by qualitatively conceptualising an Islamic credit card based on a mushāraka mutanāqisa in an in-depth manner, especially with the use of AAOIFI as a base for the conceptual analysis.
\end{abstract}

Keywords: Islamic credit cards, Mushāraka mutanāqisa, Diminishing partnership. JEL Classification: E50; E51.

\author{
Article history: \\ Received : June 23, 2020 \\ Revised : : August 25, 2020 \\ Accepted : : August 27, 2020 \\ Available online : November 15, 2020 \\ https://doi.org/10.21098/jimf.v6i4.1257
}




\section{INTRODUCTION}

\subsection{Background}

Evidence suggests that the first Islamic bank, in terms of its modern form today, was Dubai Islamic Bank in 1975, followed by Kuwait Finance House in 1977 and Bahrain Islamic Bank in 1979 (Hassan et al., 2012). Therefore, as these three banks are Islamic retail banks, rather than wholesale ones (DIB, 2020; KFH, 2020; BIsB, 2020), it may be suggested that the first Islamic banks that came into existence were initially established to provide Islamic retail banking services. Among the various retail banking products and services offered by Islamic banks, credit cards have attracted research attention (for example, Mohammed, Ismail, \& Markom, 2014) due to the Shari'a issues inherent in credit card transactions.

Credit cards play a significant role in an individuals' lives, as they allow many actions and transactions to be conducted. However, they represent an interestbased lending mechanism (Brito \& Hartley, 1995), which is one of the main prohibitions in Shari'a (Kettel, 2011; Abdul-Rahman, 2010). Arsyianti and Adelia (2019) conclude that Shari'a-compliant credit card transactions could lead to an increase in non-performing risk for Islamic banks. However, the growing demand for such credit cards has led Islamic retail banks to finding alternatives solutions in order to offer credit card services that follow Islamic financial principles (AlEnezi, 2015).

Widityani, Faturohman, Rahadi, and Yulianti (2020) have already confirmed that financial literacy makes a significant and positive contribution towards the selling of Islamic financial products. The Shari'a compliance feature of credit cards offered by Islamic banks could be enhanced through the eradication of the interestbased method of lending that underlies conventional credit cards. For example, an Islamic credit card could operate through the process of qardh hasan (benevolent loan), where the credit card provider does not charge interest on the money lent. Therefore, through the eradication of interest, such credit cards may be considered as Shari'a compliant.

Through Islamic financial engineering, there could be other forms of Islamic credit cards, such as muräbaha or tawarruq. However, there seem to be no Islamic credit cards that operate through the form of mushāraka mutanāqisa. In relation to this, a review of the literature suggests that the conceptualisation of an Islamic credit card based on a mushāraka mutanāqisa may be limited to the theoretical perspective. Furthermore, evidence indicates that several contemporary debates regarding the permissibility of existing Islamic credit cards in terms of Shari'a principles, are also taking place. An example of this was a Shari'a scholar session held by the waqf fund in the Kingdom of Bahrain, which discussed Islamic credit card structures along with the Shari'a non-compliance issues that may be associated with them $(\mathrm{CBB}, 2020)$. This may further strengthen the argument that it may be essential to address possible non-Shari'a compliance issues associated with existing Islamic credit cards, but that financially engineering new Islamic credit cards with newly innovated Shari'a compliant structures may also prove beneficial. 


\subsection{Objective}

As credit cards often represent a key role in individuals' lives, the research aims to conceptualise a new form of Islamic credit card, which may lead to deliberation. This may also fill a research gap through a conceptualisation that seems to be limited in the research field. Therefore, the following aims were developed for the research:

1. To gain understanding of a mushāraka mutanāqisa as an Islamic financial product, in addition to its critical rulings and controls according to AAOIFI; and

2. To conceptualise a mechanism for an Islamic credit card based on mushāraka mutanāqisa.

Following the introduction, the literature review starts by reviewing previous studies of Islamic credit cards. We then continue to critically review the literature to gain understanding of the mushāraka mutanāqisa as an Islamic financial product, followed by a focus on the critical rulings of a mushāraka mutanāqisa according to AAOIFI. The review concludes by summarising the critical controls of a mushäraka mutanāqisa according to AAOIFI. This is followed by the research methodology section, which explains the use of the qualitative methodology and qualitative content analysis to derive the rulings/controls of a mushāraka mutanāqisa according to AAOIFI, which were used as a base for the conceptualisation process. This conceptualises how an Islamic credit card may operate based on mushāraka mutanāqisa principles. Finally, the conclusions are drawn.

\section{LITERATURE REVIEW}

\subsection{Conceptualising Islamic Credit Cards}

The review of the literature indicates that the concept of credit cards may have been originated by conventional institutions, as the main principles underlying conventional cards do not seem to comply with Shari'a requirements (Mohammed et al., 2014). This may be due to the possibility that the majority of conventional credit cards seem to adopt interest-based lending mechanisms (Calem \& Mester 1995; Gross \& Souleles 2002, Chakravorti \& Emmons, 2003). However, the literature further tends to suggest that Islamic financial institutions have adopted credit card practices by altering specific components that contravene Shari'a requirements (Al-Enezi, 2015). This may have mainly been done through the eradication of the interest-based elements included within conventional credit cards. For example, it is suggested that various Islamic financial institutions started to issue credit cards that did not involve interest payments on amounts lent, or even in the event of late repayments (Al-Enezi, 2015). Consequently, as charging interest constitutes one of the main prohibitions of Shari'a, the eradication of this element generally enabled Islamic financial institutions to offer credit cards in line with Shari'a principles (Al-Enezi, 2015).

Other studies of the concept of Islamic credit cards relate to the issues of knowledge and religiosity influencing people's decisions on whether to opt for credit cards (Johan \& Putit, 2016). The literature also tends to suggest that the perception of consumers relating to Islamic credit card may vary (Johan et al., 2017). 
As the concept of credit cards does not necessarily contravene Shari'a requirements, but rather it is the element of interest that does, there seems to be no harm in adopting diverse methodologies to offer credit card services that meet Shari'a requirements. This may be advantageous, as credit cards may play a significant role in managing individuals' financial affairs. For example, when travelling people may find themselves in a position of necessity and require the use of a credit card to manage their affairs. This is a simple example of a possible need to utilise a credit card. As this research pertains to the development of a credit card based on mushāraka mutanāqisa, the following section discusses this concept as an Islamic financial product.

\subsection{Previous Studies of Islamic Credit Cards}

We performed a critical review of previous studies of Islamic credit cards and found that the majority have explored the behavioural aspects of their use. While Jamshidi and Hussin (2019) provide empirical evidence of Islamic credit card use from the Malaysian perspective, we also found evidence in the context of several emerging markets, such as Brunei (Ali, Yaacob, \& Salman, 2019) and Pakistan (Ali, Raza, \& Puah, 2017). Jamshidi and Hussin (2016) employed the modified technology acceptance model to ascertain the influence of perceived religiosity on Islamic credit card adoption. The model was further modified by Jamshidi and Hussin (2019), who indicated the importance of relative advantage and customer awareness as strong predictors of Islamic credit card adoption in Malaysia. Ali, Yaacob, and Salman (2019) complemented the findings of Jamshidi and Hussin (2016) and validated the propositions of the theory of reasoned action (TRA) to explain Islamic credit card adoption. Their results are also in line with the findings of Jamshidi and Hussin (2019); they recommend regulators to build awareness of Islamic financial products using online media. Ali, Raza, and Puah (2017) found a negative influence of perceived financial costs on Islamic credit card adoption in Pakistan. However, these costs were not found to be a significant predictor of Islamic credit card adoption for consumers in Brunei. Therefore, there are conflicting findings on Islamic credit adoption among emerging countries.

The growing popularity of Islamic credit cards has also attracted research attention to the Shari'a aspect of this Islamic retail product. Kahf and Mohomed (2016) discuss the criticisms of the underlying contracts used for Islamic credit cards and address the Shari'a perspectives of different card structures. Islamic financial institutions have offered credit cards based on qard (loan), kafalah (guarantee) or hawalah (transfer of debt) contracts. In an attempt to eliminate the interest clause and enhance the Shari'a compliance of credit cards, Islamic banks adopt innovative features such as a full amount payment option within the grace period, waqalah fees, tawarruq settlements, prepaid features and the Ijarah model (Kahf \& Mohomed, 2016). However, the current mode of contracts between Islamic banks and credit card holders leaves rooms for potential Shari'a compliance risk, as Islamic banks may not be able to prevent the use of Islamic credit cards for the purchase of prohibited items. Johan (2018) concludes that existing Islamic credit cards are struggling to comply with Shari'a standards. Therefore, we conceptualise an Islamic credit card which conforms to mushäraka mutanāqisa principles in order to improve Shari'a compliance and attract customer interest in such a card. 


\subsection{Mushāraka Mutanāqisa as an Islamic Financial Product}

Islamic banks operate in a manner that should adhere to Shari'a principles (AbdulRaheem, 2013). One of the main prohibitions in Shari'a is engagement in riba (Visser \& McIntosh 1998; Samiullah 1982; Ahmad et al., 2011). Therefore, several Islamic financial products have been established as a substitute for interest-based financial products. These main Islamic financial instruments include murābaha, mudhāraba, mushāraka, ijāra, and tawarruq, amongst others (Ayub, 2007).

A mushāraka mutanāqisa (diminishing partnership) is part of a mushāraka product (Ayub, 2007). In a mushāraka mutanāqisa, an Islamic bank partially finances a client by jointly purchasing an underlying asset with the client, then subsequently selling its shares (usually gradually) to the client at a higher price (Hassan et al., 2012). The literature suggests that in general, a mushäraka mutanāqisa involves two (partnership and sale) or three (partnership, lease, and sale) contracts (Alkhan, 2020). Eventually, this leads to the client attaining full ownership of the underlying asset, following the completion of the financing tenor (having purchased the share of the Islamic bank in full) (Hassan et al., 2012). As this research intends to conceptualise an Islamic credit card based on mushāraka mutanāqisa, the following section discusses some of the main features involved in a mushāraka mutanāqisa product.

\subsection{Key Features of Mushāraka Mutanāqisa}

As indicated in the previous section, a mushāraka mutanāqisa can be considered as one of the Islamic financial products that may be utilized by Islamic banks. In order to be able to conceptualize an Islamic credit card based on a mushāraka mutanāqisa, it is appropriate to focus on some key features of a mushāraka mutanāqisa based on the Accounting and Auditing Organization for Islamic Financial Institution (AAOIFI) Shari'a Standards. This is because AAOIFI standards are generally accepted by the global Islamic banking industry as an Islamic finance infrastructure organisation.

First, AAOIFI defines a mushāraka mutanāqisa as a form of partnership in which one partner promises to purchase the shares of the other partner on a gradual basis until the title deed or ownership of the equity is fully transferred to the buyer (AAOIFI, 2020). However, AAOIFI specifically mentions that both the promise and actual purchase may not be stipulated in the initial partnership contract (AAOIFI, 2020). Therefore, this indicates that the contract relating to the purchase of the shares of the other partner should be drawn up independently.

Another rule that AAOIFI mentions is that it is not allowed to stipulate in the contract and/or grant the right to any of the partners to withdraw their shares in a mushāraka mutanāqisa contract (AAOIFI, 2020). Furthermore, as one party is expected to eventually purchase the shares of their partner, this should not serve as grounds to enable one sole partner to be responsible for all related costs such as insurance and maintenance (AAOIFI, 2020). This indicates that although it is expected (through a promise) that one partner will eventually purchase the shares of the other, the initial agreement entered into is similar to that of a normal partnership agreement. The intent to purchase (and the actual purchase) are conducted through separate and independent financial agreements, in which the Shari'a rulings of the partnership (mushāraka) are still applicable to the partnership 
contract - at least until the shares of one partner are sold in full to the other partner. However, as a mushāraka mutanāqisa is considered to be type of partnership mode (for example, rather than a sale or lease mode) (Hassan et al., 2012), both parties are obliged to contribute to the capital, either by providing liquidity or tangible assets that may be used for the operations of the partnership that can be translated into a monetary value (for example: land) (AAOIFI, 2020).

Under a normal mushāraka contract, financial losses are borne in accordance with the financial contributions of each partner (AAOIFI, 2020). Therefore, as a mushāraka mutanāqisa represents a diminishing partnership, losses are borne in accordance with the equity ratio owned by each partner at the time of the loss (AAOIFI, 2020). As for profits, these should be distributed in accordance with the predetermined ratio stipulated in the partnership agreement (AAOIFI, 2020). It is evident from the AAOIFI Shari'a Standard relating to a mushāraka mutanāqisa, that although losses are solely borne by the equity contributions by each partner, profits may be attained through a ratio that may not necessarily be proportionate to the financial contributions of each (AAOIFI, 2020).

\subsection{Summary of AAOIFI Controls on Mushāraka Mutanāqisa}

Like any other Islamic financial product, there have been various studies and discussions about the permissibility of the mushāraka mutanāqisa, with a diversity of opinions on the differing forms in which an Islamic financial product can be utilised. In line with the research aim to conceptualise an Islamic credit card based on a mushāraka mutanāqisa, the study does not focus on the differences in opinion that may exist concerning such a partnership. Instead, we present below a summary that represents some of the key features pertaining to a musharraka mutanāqisa according to AAOIFI. As this may be used as a basis for rulings/ controls on the adoption of a mushāraka mutanāqisa by Islamic banks (especially Islamic banks who are required by regulators to adhere to AAOIFI standards), this summary could be used to conceptualise how an Islamic credit card could operate through a mushāraka mutanāqisa.

The above only represents some of the key features/controls of a mushāraka mutanāqisa. Since it is considered to be a segment of a normal mushäraka, it is important to note that the general rulings of a normal mushāraka may also apply to a mushāraka mutanāqisa. However, in line with the research aims, the above table only represents some key features of a mushāraka mutanāqisa according to AAOIFI standards. This is in order to help clarify some of the basic features/controls of a mushāraka mutanāqisa according to the AAOIFI.

The following section discusses the research methodology used for the research, and also clarifies how the above-summarized table was used to help develop a conceptualisation strategy. 
Table 1.

Summary of AAOIFI Controls for a Mushāraka Mutanāqisa

\begin{tabular}{|c|c|c|}
\hline Ref: & Feature / Rule / Control & $\begin{array}{c}\text { Base: AAOIFI } \\
\text { Shari'a Standard } \\
\text { No. 12, Paragraph: }\end{array}$ \\
\hline 1 & $\begin{array}{l}\text { Both partners should contribute to the capital (financially, or in } \\
\text { the form of an asset used for operations that can be translated into } \\
\text { monetary value). }\end{array}$ & $5 / 4$ \\
\hline 2 & $\begin{array}{l}\text { A promise by a partner to (gradually) purchase the share of the other } \\
\text { partner should be given through a separate (independent) contract. }\end{array}$ & $5 / 1$ \\
\hline 3 & $\begin{array}{l}\text { The actual purchase of the shares of the other partner should also be } \\
\text { executed through a separate (independent) contract. }\end{array}$ & $5 / 1$ \\
\hline 4 & $\begin{array}{l}\text { The partnership contract does not grant the right to either partner to } \\
\text { withdraw his share from the capital. }\end{array}$ & $5 / 2$ \\
\hline 5 & $\begin{array}{c}\text { Both parties must be responsible for the cost/maintenance for the } \\
\text { operations. }\end{array}$ & $5 / 3$ \\
\hline 6 & $\begin{array}{c}\text { Profits are made in accordance with the predetermined ratio or } \\
\text { agreement. }\end{array}$ & $5 / 5$ \\
\hline 7 & $\begin{array}{l}\text { Losses can solely be borne in accordance with the contributions made } \\
\text { by each partner. }\end{array}$ & $5 / 4$ \\
\hline
\end{tabular}

Source: Authors' findings

\section{METHODOLOGY}

The research used qualitative methodology. As the study is conceptual, qualitative content analysis was employed as it involves a theory-guided approach to text analysis, using a categorical strategy (Kohlbacher, 2016; Titscher et al., 2000; Bryman, 2004). Krippendorff (1989, p. 404) explains that the "most obvious sources of data appropriate for content analysis are texts to which meanings are conventionally attributed...". The theories explored in the literature section are used as a base for the analysis in order to be able to conceptualise an Islamic credit card based on a mushāraka mutanāqisa. Therefore, a categorical strategy was used for the conceptualisation process. Based on the literature reviewed (summarised in Table 1), the following categories emerged as key features to help the conceptualisation process:

Table 2.

Categorical Conceptualisation Process

\begin{tabular}{|c|c|c|}
\hline $\begin{array}{l}\text { Category } \\
\text { No. }\end{array}$ & Category & $\begin{array}{l}\text { Reference Guided } \\
\text { from Theory }\end{array}$ \\
\hline 1 & Underlying contract for the Islamic credit card. & $\begin{array}{l}\text { Definition of Mushāraka } \\
\text { Mutanāqisa (section 2) }\end{array}$ \\
\hline 2 & Partners' contributions to the capital. & AAOIFI SS. 12 Par. 5/4 \\
\hline 3 & Promise by one partner to purchase the shares of the other. & AAOIFI SS. 12 Par. 5/1 \\
\hline 4 & Executing a gradual purchase/sale contract by the partners. & AAOIFI SS. 12 Par. 5/1 \\
\hline 5 & $\begin{array}{l}\text { Not possible for either partner to withdraw their share of } \\
\text { the capital, with both parties liable for operational costs/ } \\
\text { maintenance. }\end{array}$ & $\begin{array}{l}\text { AAOIFI SS. } 12 \\
\text { Par. } 5 / 2 \& 5 / 3\end{array}$ \\
\hline 6 & $\begin{array}{l}\text { Profits distributed according to the predetermined agreement, } \\
\text { while losses borne in accordance with an equity rasio. }\end{array}$ & $\begin{array}{l}\text { AAOIFI SS. } 12 \\
\text { Par. } 5 / 4 \& 5 / 5\end{array}$ \\
\hline
\end{tabular}


To elaborate, the first category shown in Table 2 involves the use of the definition of a mushāraka mutanāqisa (in accordance with the literature) in order to conceptualise the underlying contract for the Islamic credit card. Thereafter, categories two to six above represent certian key AAOIFI rulings and controls for a mushāraka mutanāqisa, which are used as a basis for the conceptualisation process. The following section discusses the conceptualisation of an Islamic credit card based on a mushāraka mutanāqisa, using the methodology explained in this section.

\section{RESULTS AND ANALYSIS}

\subsection{Conceptualisation of an Islamic Credit Card Based on a Mushāraka Mutanāqisa}

As explained in the research methodology section, this section qualitatively conceptualises the development of an Islamic credit card based on the theory and set of rulings/controls that may apply to a mushāraka mutanāqisa. The following conceptualisation process was conducted in accordance with the categories displayed in the research methodology section, which were mainly based on AAOIFI guidelines.

\subsection{Underlying Contract for the Islamic Credit Card}

Like any other credit card, a client is expected to sign an agreement prior to the issuance of a credit card. Therefore, in this case, the Islamic bank and the client enter into a mushäraka (partnership) agreement, which means that when clients purchase a certain asset (through the credit card) for investment purposes, they are doing so on behalf of both partners. Consequently, such an agreement may require the involvement of an additional wakalah (agency) agreement, whereby the Islamic bank enables the client to act on behalf of both partners (the client and Islamic bank) when executing a transaction. Therefore, this leads to two agreements, one for the mushäraka and the other for the wakalah. To help clarify this process further, Figure 1 shows the contractual relationship between the client and Islamic bank:

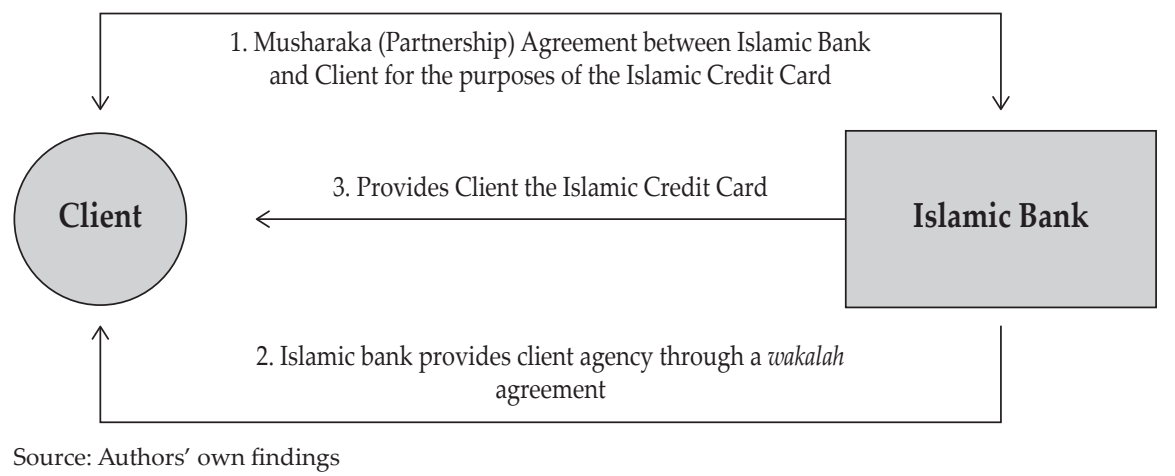

Figure 1.

Contractual Relationship between Client and Islamic Bank 
As the theories explored in the literature section suggest that both partners need to contribute to the capital, the following section discusses how this may be undertaken in a practical way.

\subsection{Partners' Contribution to the Capital}

As explained in the literature section, since both partners are required to contribute to the capital in the partnership (as opposed to a mudhāraba, for example, where only one party contributes), an Islamic credit card may be based on a mechanism whereby the client is required to deposit a specific amount (into the credit card account) as a contribution to the capital, and the Islamic bank may then also provide its share of the capital into the account. For example, if a client deposits USD 1000, the Islamic bank may then provide the credit card with access to USD 2000, with both parties contributing USD 1000 each. Therefore, this may adhere to AAOIFI Shari'a Standard No. 12 paragraph 5/4 relating to the mushāraka mutanāqisa.

Figure 2 shows how both parties may contribute to the capital for the musharaka, which may be credited into the Islamic credit card account.

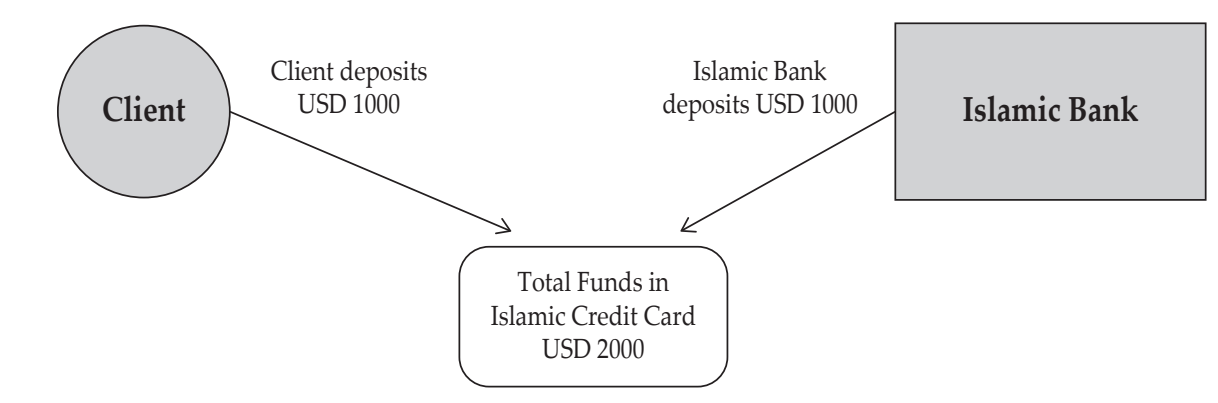

\begin{tabular}{c|c|c|c} 
& Client & Islamic Bank & Total \\
Mushāraka Card & USD 1000 & USD 1000 & USD 2000
\end{tabular}

Source: Authors' own findings

Figure 2.

Contribution of Both Parties to the Capital in an Islamic Credit Card Account

However, as the literature suggests that the initial mushāraka contract should not include a promise by the client to purchase the shares of the Islamic bank, at this stage the initial agreement represents a normal partnership agreement.

The following section discusses how the concept of mushāraka mutanāqisa may be put into practice, starting with the promise of the client to the Islamic bank to (gradually) purchase its shares.

\subsection{Promise by One Partner to Purchase the Shares of the Other}

As explained in the previous section, a mechanism was conceptualised whereby both parties contribute to the capital. When a client purchases a certain asset for 
investment purposes (for example, an asset to be leased) through acredit card, the client may then make a promise to the Islamic bank to purchase its shares on a gradual basis. In practical terms, the promise may be delivered online through the e-banking system. Therefore, an organised mechanism may be established through the e-banking system in which certain processes, contracts and agreements may be entered into based on a set of chronological orders (for example, the promise is given following the entry into a partnership) in order to adhere to AAOIFI stipulations.

Figure 3 conceptualises the accounts of a mushāraka mutanāqisa Islamic credit card, and further shows how the promise by the client to gradually purchase the shares of the Islamic bank can be made using various options.

\section{E-Banking System}

Islamic Credit Card Account

\begin{tabular}{l|c|c|c} 
& Client Share & Islamic Bank Share & Total \\
Mushāraka Card & USD 1000 & USD 1000 & USD 2000 \\
Executed Transactions & USD 400 & USD 400 & USD 800 \\
$\begin{array}{l}\text { Share in Mushäraka Investment } \\
\text { XYZ }\end{array}$ & $50 \%$ & $50 \%$ & $100 \%$ \\
Remaining Balance & USD 600 & USD 600 & USD 1200
\end{tabular}

Options to purchase Islamic Bank's Share :

\begin{tabular}{|l|l|l|}
\multicolumn{4}{|c|}{ Promise to Purchase Islamic Bank Share (50\%) } & & Execute \\
\hline Option 1: Over 6 months at Price USD 400 + USD 200 & Promise & Execute \\
\hline Option 2: Over 12 months at Price USD 400 + USD 300 & Promise & Execute \\
\hline Option 3: Over 18 months at Price USD 400 + USD 400 & Promise & Execute \\
\hline
\end{tabular}

Source: Authors' Own findings

Figure 3.

Promise through the E-Banking System

Figure 3 shows an example of how a client can promise to purchase the shares of an Islamic bank through various options. The client may not be able to make a transaction prior to providing the bank with the promise to purchase its shares. This is because the terms, agreements, and payment methods/pricing will be executed according to the promise. The following section discusses how the client may make a transaction following the promise.

\subsection{Execution of a Gradual Purchase/Sales Contract by the Partners}

Following the signing of the agreement, the contributions made by the partners, and a transaction executed by a client on behalf of the partners, the previous section conceptualised how the client provides an Islamic bank with a promise through the e-banking system. 
The Islamic bank will provide multiple promise options to clients to enable it sell its shares to them through the e-banking system. Figure 3 shows an example of how an Islamic bank could offer to gradually sell its shares to the client within six months, twelve months or eighteen months, with the client able to choose which option to opt for. Following the selection of a promise option, in which the terms and payment conditions/schedule are clear, the client can then execute the transaction online through the e-banking system.

Figure 4 shows how the execution of the promise would be available to the client following the selection of a certain option (for example, the client selects promise option two):

\section{E-Banking System}

Islamic Credit Card Account

\begin{tabular}{|c|c|c|c|}
\hline & Client Share & Islamic Bank Share & Total \\
\hline Mushāraka Card & USD 1000 & USD 1000 & USD 2000 \\
\hline Executed Transactions & USD 400 & USD 400 & USD 800 \\
\hline $\begin{array}{l}\text { Share in Mushāraka Investment } \\
\text { XYZ }\end{array}$ & $50 \%$ & $50 \%$ & $100 \%$ \\
\hline Remaining Balance & USD 600 & USD 600 & USD 1200 \\
\hline
\end{tabular}

Options to purchase Islamic Bank's Share :

\begin{tabular}{|l|l|l|}
\hline \multicolumn{4}{|c|}{ Promise to Purchase Islamic Bank Share (50\%) } & \\
\hline Option 1: Over 6 months at Price USD 400 + USD 200 & Promise & Execute \\
\hline Option 2: Over 12 months at Price USD 400 + USD 300 & Promise & Execute \\
\hline Option 3: Over 18 months at Price USD 400 + USD 400 & Promise & Execute \\
\hline
\end{tabular}

Source: Authors' own findings

\section{Figure 4.}

Execution of the Promise by the Client

As can be seen in Figure 4, once the client has made a promise to the Islamic bank to purchase its shares, the e-banking system enables the client to then execute the transaction. The process of the diminishing partnership starts at this stage, where the mushāraka transaction now becomes a mushāraka mutanāqisa one. According to the reviewed literature, this seems to be in line with AAOIFI requirements. Hereafter, each time clients make a periodic payment, the shares of the Islamic bank are gradually transferred to them. In accordance with the agreed terms and payment conditions, the schedule of paid amounts and transfer shares from the Islamic bank to the client may simply be visible in the e-banking system for operational purposes. Figure 5 illustrates this process in more detail. 


\section{E-Banking System}

Mushāraka Mutanāqisa Executed (for investments XYZ)

Agreed price: USD 700

Tenor: 12 Months

Payment Schedule:

\begin{tabular}{|c|c|c|c|}
\hline & Payment by Client & Client Share & Islamic Bank Share \\
\hline As of Execution Date & 0 & $50 \%$ & $50 \%$ \\
\hline Month 1 & USD 58.3 & $54.2 \%$ & $45.8 \%$ \\
\hline Month 2 & USD 58.3 & $58.4 \%$ & $41.6 \%$ \\
\hline Month 3 & USD 58.3 & $62.6 \%$ & $37.4 \%$ \\
\hline Month 4 & USD 58.3 & $66.8 \%$ & $33.2 \%$ \\
\hline Month 5 & USD 58.3 & $71 \%$ & $29 \%$ \\
\hline Month 6 & USD 58.3 & $75.2 \%$ & $24.8 \%$ \\
\hline Month 7 & USD 58.3 & $79.4 \%$ & $20.6 \%$ \\
\hline Month 8 & USD 58.3 & $83.6 \%$ & $16.4 \%$ \\
\hline Month 9 & USD 58.3 & $87.8 \%$ & $12.2 \%$ \\
\hline Month 10 & USD 58.3 & $92 \%$ & $8 \%$ \\
\hline Month 11 & USD 58.3 & $96.2 \%$ & $3.8 \%$ \\
\hline Month 12 & USD 58.3 & $100 \%$ & 0 \\
\hline
\end{tabular}

Source: Authors' own findings

Figure 5.

Gradual Transfer of Shares from the Islamic Bank to Client

Following the execution of the mushāraka mutanāqisa agreements through the e-banking system, Figure 5 displays the schedule of payments by the client and the diminishing partnership percentages of the Islamic bank.

\subsection{Barring of Either Partner from Withdrawing Their Share of the Capital, with Both Parties Liable for Operational Costs/Maintenance}

In order to adhere to AAOIFI requirements in terms of the barring of either partner from withdrawing their share of the capital, as stipulated in AAOIFI Shari'a Standard No. 12 paragraph 5/2, the underlying Islamic credit card agreement should explain this restriction clearly.

From an operational perspective, however, adopting such a strategy should theoretically be a simple one. First, as previously conceptualised, both the client and Islamic bank contribute to the Islamic credit card account. Therefore, neither party should be able to withdraw their share and should adhere to the agreement entered into. For example, if the client deposits USD 1000 into the credit card account, they will not be able to withdraw this share.

On the other hand, if operational/maintenance costs are incurred by the partners (as stipulated in AAOIFI Shari'a Standard paragraph 5/3), these can be borne through the Islamic credit card account. Since both parties have contributed to the capital on the credit card, such costs will be distributed according to shares of each partner. According to these two requirements, Figure 6 clarifies the barring 
of either partner from withdrawing their share of capital, and further highlights from an account perspective in what cases costs may be deducted in order to to be in line with AAOIFI requirements.
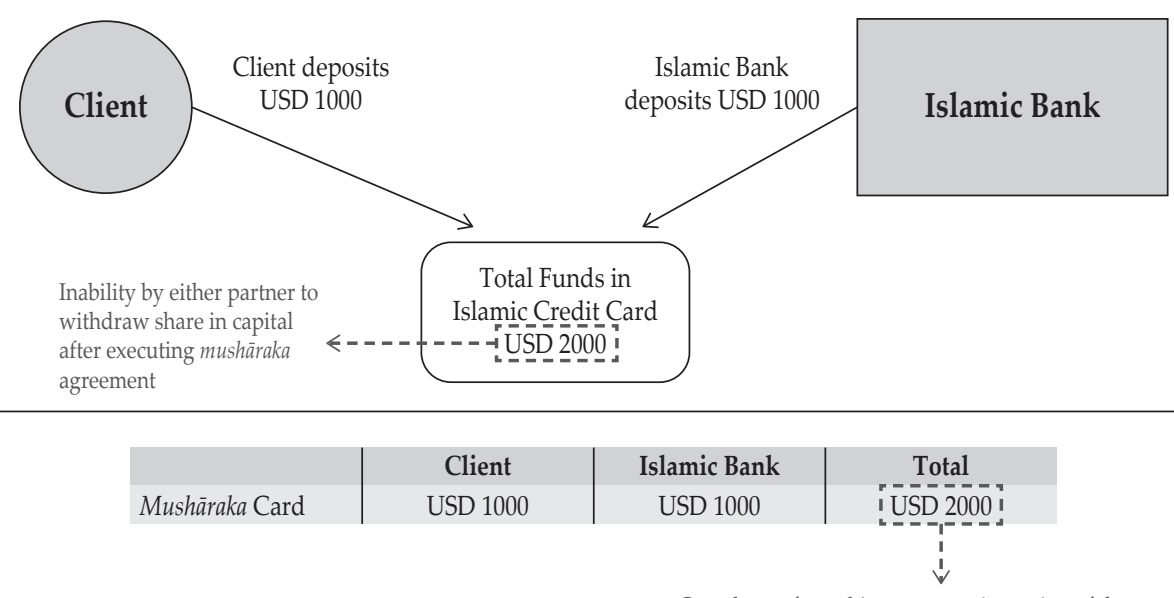

Costs borne from this account as it consists of the account with the shared funds by both partners

Source: Authors' own findings

Figure 6.

Barring or partners from withdrawing capital / costs borne by the Islamic credit card account

\subsection{Profits distributed according to the predetermined agreement, with losses borne in accordance with the equity ratio}

Since the concept of a mushäraka mutanāqisa involves a gradual process whereby the client purchases the shares of the Islamic bank, when entering into the agreement for the process of purchasing such shares, the distribution of profit/ loss should also be clearly explained in the contract. Consequently, in order to adhere to AAOIFI Shari'a Standard No. 12 paragraph 5/4, a predetermined ratio or agreement should be clearly stipulated in the contract. On the other hand, in order to adhere to AAOIFI Shari'a Standard No. 12 paragraph 5/5, the contract should also clearly stipulate that losses are borne in accordance with the equity capital of each partner. This is mainly because as the equity of the Islamic bank decreases, the percentage share of its losses also decrease over time. Therefore, all the necessary conditions should be made very clear in the contract.

In order to simplify the conceptualised Islamic credit card based on a mushāraka mutanāqisa, the following section summarises the conceptualisation process explained in this and previous sections.

\subsection{Summary of the Conceptualisation Process}

The previous sections conceptualised how an Islamic credit card could operate based on a mushāraka mutanāqisa. This was mainly done by using a categorical 
strategy that was derived from the review of literature section and AAOIFI Shari'a Standard No. 12 pertaining to mushäraka mutanāqisa. The results of the conceptualisation process are summarised as follows:

(a) The client and Islamic bank sign a mushäraka agreement related to the Islamic credit card. The Islamic bank thereafter provides wakalah (agency), which enables the client to act on behalf of the Islamic bank when making transactions using the Islamic credit card. The Islamic bank then issues the credit card to the customer.

(b) The account for the issued Islamic credit card consists of payments made by both the client and Islamic bank. For example, both the client and Islamic bank contribute USD 1000 each, meaning the account contains USD 2000, being the total capital contribution by both partners (client and Islamic bank).

(c) When a client purchases an asset with the credit card (with the transaction being executed on behalf of both partners through the wakalah arrangement), ownership of the asset now belongs to both the client and Islamic bank (for example, 50\% each). Consequently, through the e-banking system the Islamic bank offers the client a number of options (for example, payment schedules), from which the client makes a promise to the bank to purchase its shares on a gradual basis. The client then makes the promise to purchase the shares of the Islamic bank by simply choosing a promise option through the e-banking system . The promise should include a clear, predetermined purchase price and payment schedule.

(d) Following the promise made by the client to the Islamic bank, the client can then execute the transaction through the e-banking system, and start making the periodic payments according to the agreed payment schedule. Once executed, the e-banking system will clearly show the payment schedule and the shares tranferred from the Islamic bank to the client following each periodic payment. The partnership now gradually diminishes in accordance with the mushāraka mutanāqisa agreement made by both parties.

(e) It must be clearly stipulated in the contract that neither party can withdraw their share of the capital from the partnership agreement. Therefore, once the agreement has been made and both parties have contributed their share to the mushāraka capital, the e-banking system should disable both parties from withdrawing their capital. This is in order to be in line with AAOIFI Shari'a Standard No. 12, paragraph 5/2. Furthermore, the operational costs of the mushäraka investment will be borne by both parties through the Islamic credit card account to which both parties have contributed in order to comply with AAOIFI Shari'a Standard No. 12, paragraph 5/3.

(f) In the event that profits (or losses) are generated, the profits will be disbursed to the partners according to a predetermined ratio, while losses will be borne in accordance with the partners' contributions to the mushäraka capital. This is in order to adhere to AAOIFI Shari'a Standard No. 12, paragraphs 5/4 and 5/5 respectively.

(g) A mushāraka mutanāqisa-based Islamic credit card can have a Bai' salam clause, which would allow cardholders to pay the monthly balance in full using the e-banking system. However, the delivery of the asset may be deferred according to the pre-specified time. 
The above summary represents the key points of the conceptualisation process, with detailed analysis provided for each factor in the previous sections. Where relevant, figures/diagrams have also been provided for the above points to illustrative the Islamic credit card operation through a mushāraka mutanāqisa. However, to further conceptualise the overall process, Figure 7 shows how a mushäraka mutanāqisa Islamic credit card would operate, based on the summarised key points in this section.

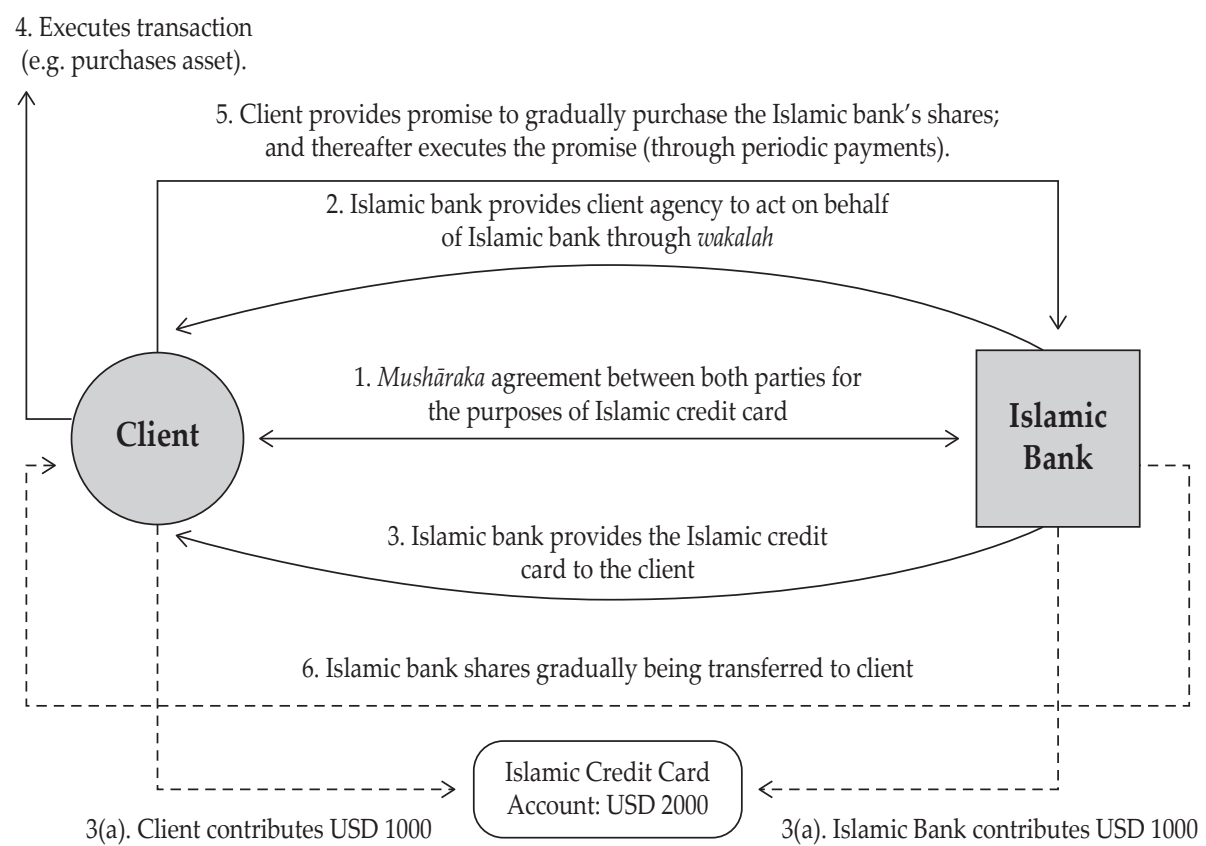

Source: Authors' own findings

Figure 7.

Summary of Conceptualisation

\subsection{Analysis}

Sillah (2017) identifies various types of Islamic credit cards, including ones based on murābaha (cost-plus sale), tawarruq (monetisation), and bai al-inah, which have come under scrutiny in terms of their degree of Shari'ah compliance. Amin (2013) concludes that customers prefer Shari'a-compliant credit cards that restrict interest-based transactions and continue to resort to different Islamic credit cards as alternatives. Previous studies have discussed various forms of Islamic credit cards which have come under scrutiny from a Shari'a perspective (e.g., Kahf \& Mohamed, 2016). Shari'ah scholars have analysed the permissibility of contracts with standard templates that allow fees to become a negotiable item and ruled such products to be Shari'a-compliant. As long as interest elements are not present, fees charged by Islamic banks are permissible as they represent a valid charge for services provided to the cardholder. 
However, such a decision is not uniform across all types of contracts related to the diverse types of credit card offered by Islamic banks. For example, in a qardbased contract, the conditions for the trade of debts are valid since the transactions involve cash. As such, Islamic banks are not permitted to charge additional fees to cardholders on the amount withdrawn. The qard feature in a contract becomes invalid if payment for a purchase is made in advance. In wakalah-based contracts, Shari'a scholars have found the presence of the hawalah element (transfer of debt), which is not permissible in Shari'ah (Kahf \& Mohamed, 2016). Johan (2018) concludes that existing Islamic credit cards are struggling to comply with Shari'a standards, which strengthens the argument for developing an innovative Islamic credit card based on a contractual framework permissible in Shari'ah.

Following the conceptualisation process, our results reveal that the concept of financially engineering a mushāraka mutanāqisa Islamic credit card is theoretically valid. Our conceptual Islamic credit card model under a mushāraka mutanāqisa contract contributes towards solving the Shari'a compliance issues inherent in previous products. We integrate the wakalah concept into our Islamic credit card model, which enables the client to act on behalf of the issuer of the card. Our proposed model also makes use of financial technologies (FinTech) to encourage clients to purchase the share of the credit card issuer on a gradual basis. The application of the suggested mushāraka mutanāqisa Islamic credit card model may be beneficial for the sustainable growth of the Islamic finance industry and regulators could benefit by adopting our proposed Islamic credit card model as a pilot project.

\section{CONCLUSION AND RECOMMENDATIONS}

\subsection{Conclusion}

In the modern world, credit cards may play an important role for individuals and corporations. However, conventional credit cards generally operate on interestbased lending mechanisms, which may conflict with Shari'a rulings. Through Islamic financial engineering, Islamic financial institutions have started to innovate Islamic credit cards, mainly by eradicating the element of interest. For example, such cards may be based on a qardh hasan (benevolent loan). Other examples of Islamic credit cards include murābaha-based ones. However, there seem to be no cards based on the mushäraka mutanāqisa; the literature review indicated that this conceptualisation might exist, but appears to be minimal.

Mainly using AAOIFI Shari'a Standard no. 12 "Partnership (Musharakah) and Modern Corporations" concerning the mushāraka mutanāqisa, a qualitative content analysis summarised the key mushāraka mutanāqisa factors and controls based on AAOIFI guidelines. These factors were then used as a base to conceptualise an Islamic credit card based on a mushāraka mutanāqisa. This approach was taken because AAOIFI seems to be globally accepted by Islamic financial institutions, so adhering to their principles would be beneficial when conceptualising an Islamic financial instrument.

The findings indicate that developing an Islamic credit card based on a mushāraka mutanāqisa is feasible, with the Islamic bank and client initially entering into a partnership agreement, followed by the Islamic bank providing agency to 
the client through a wakalah. Both the client and the Islamic bank would contribute to the capital in the Islamic credit card account. When clients purchase an asset for themselves (and on behalf of the Islamic bank), they make a promise to the bank to gradually purchase its shares, according to an agreed payment schedule. The shares of the Islamic bank will therefore be gradually transferred to the client following each periodic payment. In the event of profits or losses, the former will be distributed according to a predetermined ratio, while the latter are borne according to the capital contribution made by each partner. Furthermore, operational or maintenance costs can be paid from the Islamic credit card account, since it is a shared account, and AAOIFI mandates that both parties are liable for such costs.

\subsection{Recommendations}

The study has contributed to the knowledge by providing a contemporary indepth analysis and conceptualisation of an Islamic credit card based on a mushāraka mutanāqisa, which should complement the literature and lead to discussion. After around fifty years since Islamic banking was first launched, it is time to consider different products and services that add to the Islamic banking industry's offerings.

Although the terminology may differ, the term 'credit card' is used for clarification purposes. As the Islamic bank in a mushāraka may not necessarily be providing credit to the client, but rather contributing its share of the capital, the terminology for such a concept may need to be different, such as a mushāraka card. Alternatively, since the client intends to purchase the shares of the Islamic bank gradually, it could also be referred to as a mushäraka mutanāqisa card.

We conclude from the research that establishing a card based on mushāraka or mushāraka mutanāqisa as an Islamic financial product may be theoretically feasible. We suggest implementing the initiative as a pilot project, during which empirical analysis could be conducted on how a mushāraka or mushāraka mutanāqisa card may operate, in addition to noting its key advantages and disadvantages. This would be very useful for the Islamic retail banking industry in terms of innovation and product development.

We conclude by indicating the limitations of the research. First, as it is a conceptual study, there are no empirical results in terms of analysing the positive/ negative traits of a mushāraka card. Second, there is evidence that the AAOIFI Shari'a board was officially revisiting and editing AAOIFI Shari'a Standard (SS) No. 2 (of which credit cards are a part) during the research period. Therefore, it was not possible to review what could be informative for the conceptualisation of a new Islamic credit card. 


\section{REFERENCES}

AAOIFI. (2020). Shari'ah Standards, [Online] Available from: http://aaoifi.com/ shariaa-standards/?lang=en, [Accessed 16 January 2020].

Abdul-Raheem. (2010). Islamic Banking: Principles, Practices and Performance. India: New Century Publications.

Abdul-Rahman, Y. (2010). The Art of Islamic Banking and Finance - Tools and Techniques for Community-Based Banking. New Jersey: Wiley.

Ahmad, A., Rehman, K., \& Humayoun, A. (2011) Islamic Banking and Prohibition of Riba/Interest. African Journal of Business Management, 5(5), 1763-1767.

Al-Enezi, M. (2015). Figh Al-Handasa Al-Maliya Al-Islamiya. Qassim: Qassim University.

Alkhan, A. (2020). Analyzing the Practice of Musharaka Mutanaqisa in the Islamic Banking Industry: The Kingdom of Bahrain as a Case Study. Asian Economic and Financial Review, 10(3), 275-288.

Ali, Q., Yaacob, H., \& Salman, A. (2019). The Acceptance of Islamic Credit Card in Brunei. Journal of Islamic Banking and Finance, 38, 80.

Ali, M., Raza, S. A., \& Puah, C. H. (2017). Factors Affecting to Select Islamic Credit Cards in Pakistan: the TRA Model. Journal of Islamic Marketing, 1-27.

Amin, H. (2013). Factors Influencing Malaysian Bank Customers to Choose Islamic Credit Cards. Journal of Islamic Marketing, volume/issue missing 245-263.

Arsyianti, L. D., \& Adelia, A. (2019). Sharia Compliance-Credit Card Exposure and Utilization in the Growing Digital Economy. Journal of Islamic Monetary Economics and Finance, 5(4), 891-918.

Ayub, M. (2007). Understanding Islamic Finance. England: John Wiley \& Sons, Ltd.

BIsB. (2020). Bahrain Islamic Bank [Online] Available from: https://www.bisb.com/ [Accessed 16 January 2020].

Brito, D., \& Hartley, P. (1995). Consumer Rationality and Credit Cards. Journal of Political Economy, 103(2), 400-433.

Bryman, A. (2004). Social Research Methods. New York: Oxford University Press.

Calem, P., \& Mester, L. (1995) Consumer Behavior and the Stickiness of CreditCard Interest Rates. The American Economic Review, 85(5), 1327-1336.

CBB. (2020) Banking [Online] Available from: https://www.cbb.gov.bh/banking/ [Accessed 7 August 2020].

Chakravorti, S., \& Emmons, W. (2003) Who Pays for Credit Cards? Journal of Consumer Affairs, 37(2), 208-230.

DIB. (2020) Dubai Islamic Bank [online] Available from: https://www.dib.ae/ [Accessed 16 January 2020].

Gross, D., \& Souleles, N. (2002) Do Liquidity Constraints and Interest Rates Matter for Consumer Behavior? Evidence from Credit Card Data. Quarterly Journal of Economics, 117(1), 149-185.

Hassan, Kayed, and Oseni. (2012) Introduction to Islamic Banking and Finance: Principles and Practice. Edinburgh: Pearson Education Limited.

Jamshidi, D., \& Hussin, N. (2016). Islamic Credit Card Adoption Understanding: When Innovation Diffusion Theory Meets Satisfaction and Social Influence. Journal of Promotion Management, 22(6), 897-917.

Jamshidi, D., \& Hussin, N. (2016). Forecasting Patronage Factors of Islamic Credit Card as a New e-commerce Banking Service. Journal of Islamic Marketing, 7(4), $1-34$. 
Jamshidi, D., \& Kazemi, F. (2019). Innovation Diffusion Theory and Customers' Behavioral Intention for Islamic Credit Card. Journal of Islamic Marketing, 1-31. Johan, Z., and Putit, L. (2016). Conceptualizing the Influences of Knowledge and Religiosity on Islamic Credit Card Compliance. Procedia Economics and Finance, 37, 480-487.

Johan, Z., Hussain, M., Putit, L., Dali, N., \& Hafit, N. (2017) Consumers' Perception of Islamic Credit Cards: An Explanatory Study. Pertanika Journal of Social Science and Humanities, 25 (Special Issue), 179-196.

Johan, Z. J. (2018). Shariah Compliant Credit Cards: Disputes and Steps Forward. Journal of Emerging Economies and Islamic Research, 6(1), 44-54.

Kettel, B. (2011) Introduction to Islamic Banking and Finance. United Kingdom: Wiley. KFH (2020) Kuwait Finance House [Online] Available from: https://www.kfh.com/ en/home/Personal.html [Accessed 16 January 2020].

Kahf, M., \& Mohomed, A. (2016). Credit cards: Contemporary Issues from Economic and Shariah Perspective. Journal of King Abdulaziz University: Islamic Economics, 29(1), 1-24.

Kohlbacher, F. (2016). The Use of Qualitative Content Analysis in Case Study Research. Qualitative Social Research, 7(1).

Krippendorff, K. (1989). Content Analysis. In E. Barnouw, G. Gerbner, W. Schramm, T.L. Worth, \& L. Gross (Eds.), International Encyclopedia of Communication (pp. 403-407), New York, NY: Oxford University Press. [Online] Available from: https://core.ac.uk/download/pdf/76383495.pdf [Accessed 7 August 2020].

Mohammed, M., Ismail, R., \& Markom, R. (2014). Potential Jurisprudential Adaptation for the Tripartite Credit Card Transaction from an Islamic Perspective, Arab Law Quarterly, 28(1), 317-365.

Samiullah, M. (1982). Prohibition of Riba (Interest) \& Insurance in the Light of Islam. Islamic Studies, 21(2), 53-76.

Sillah, B. (2017). Islamic Credit Cards: How Do They Work? And Is There a Better Alternative. Journal of Islamic Banking and Finance, 5(2), 1-8.

Titscher, S. Meyer, M. Wodak, R. \&Vetter, E. (2000). Methods of Text and Discourse Analysis. London: Sage Publications.

Visser, W. \& McIntosh, A. (1998). A Short Review of the Historical Critique of Usury. Accounting, Business, E Financial History, 8(2), 175-189.

Widityani, S. F., Faturohman, T., Rahadi, R. A., \& Yulianti, Y. (2020). Do SocioDemographic Characteristics and Islamic Financial Literacy Matter for Selecting Islamic Financial Products among College Students in Indonesia? Journal of Islamic Monetary Economics and Finance, 6(1). 
This page is intentionally left blank 